\title{
Mammals from 'down under': a multi-gene species-level phylogeny of marsupial mammals (Mammalia, Metatheria)
}

Laura J May-Collado, C. William Kilpatrick, Ingi Agnarsson

Marsupials or metatherians are a group of mammals that are distinct in giving birth to young at early stages of development and have prolonged investment in lactation. The group consists of nearly 350 extant species, including kangaroos, koala, possums, and their relatives. Marsupials are an old lineage thought to have diverged from early therian mammals some 160 million years ago in the Jurassic, and have a remarkable evolutionary and biogeographical history, with extant species restricted to the Americas, mostly South America, and to Australasia. Although the group has been the subject of decades of phylogenetic research the marsupial tree of life remains controversial, with most studies focusing on only a fraction of the species diversity within the infraclass. Here we present the first Methaterian species-level phylogeny including $80 \%$ of the extant marsupial species and five nuclear and five mitochondrial markers obtained from Genbank and a recently published retroposon matrix. Our primary goal is to provide a summary phylogeny that will serve as a tool for comparative research. We evaluate the extent to which the phylogeny recovers current phylogenetic knowledge based on the recovery of "benchmark clades" from prior studies-unambiguously supported key clades and undisputed traditional taxonomic groups. The Bayesian phylogenetic analyses recovered nearly all benchmark clades but failed to find support for the suborder Phalagiformes. The most significant difference with previous published topologies is the support for Australidelphia as a group containing Microbiotheriidae, nested within American marsupials. However, a likelihood ratio test shows that alternative topologies with monophyletic Australidelphia and Ameridelphia are not significantly different than the preferred tree. Although, further data are needed to solidify understanding of Methateria phylogeny, the new phylogenetic hypothesis provided here offers a well resolved and detailed tool for comparative analyses, covering the majority of the known species richness of the group. 
2 Mammals from 'down under': a multi-gene species-level phylogeny of marsupial

3 mammals (Mammalia, Metatheria)

4

5 Laura J May-Collado ${ }^{\mathrm{a}, \mathrm{b}}$, C William Kilpatrick ${ }^{\mathrm{a}}$, \& Ingi Agnarsson ${ }^{\mathrm{a}}$

6

7

8

9 a Department of Biology, University of Vermont, 109 Carrigan Drive, Burlington, Vermont 05405

10 b Department of Environmental Science and Policy, George Mason University, MSN 5F2, 4400

11 University Drive, Fairfax VA 22030

12

13

14

$15 *$ Corresponding author

16 E-mail: 1maycollado@gmail.com,

17 Phone: (802) 656-8646

18

19

20

21

22

23

24 Introduction 
25 The infraclass Metatheria contains seven mammalian orders that share a reproductive strategy, giving

26 birth to undeveloped young and having prolonged investment in lactation (Aplin \& Archer, 1987). The

27 group includes the familiar Australian megafauna, such as kangaroos and koalas, as well as some

28 enigmatic mammals such as wombats, the Tasmanian devil, and the unique South American Monito

29 del Monte. Many species are at risk of extinction (Isaac et al., 2007) and two marsupial families have

30 recently gone extinct, Thylacinidae (1936), and Chaeropodidae ( 1950). Marsupials have a rather

31 unusual geographic distribution mostly inhabiting Australasia and South America (Nilsson et al.,

32 2004), with a few genera having relatively recently crossed the Panamanian isthmus and one species

33 reached northern North America, the Virginia opossum. Most prior phylogenetic work has suggested

34 that marsupials colonized Australia twice via Antarctica/South America during the breakup of

35 Gondwanaland (Nilsson et al., 2004). However, a recent study supports the monophyly of the

36 Australasian marsupials and thus that marsupials reached Australasia in a single migration event

37 (Nilsson et al., 2010), and then diversified with over 200 extant species in the region.

Marsupials are typically classified into two major cohorts the Australidelphia and the

39 Ameridelphia (Aplin \& Archer, 1987; Marshall et al., 1990) based in part on differences of the ankle

40 joints (Szalay, 1982). Australidelphia consists of five orders, Dasyuromorphia (carnivorous marsupials

41 and marsupial mice), Peramelemorphia (bilbies and bandicoots), Notoryctemorphia (marsupial moles),

42 Diprotodontia (koalas, wombats, kangaroos, and possums), and the South American order

43 Microbiotheria (monito del monte). Ameridelphia consist of two orders Didelphimorphia (opossums)

44 and Paucituberculata (shrew oposums), mainly distributed in South America (Gardner, 2005a-b). Most

45 recent studies, however, have shown that Ameridelphia is non-monophyletic and thus this

46 classification is inconsistent with phylogenetic knowledge (Horovitz \& Sánchez-Villagra, 2003;

47 Nilsson et al., 2010).

While the phylogenetics of marsupials has received much attention in recent years, the 
marsupial tree of life remains incompletely resolved (Nilsson et al., 2010). Most studies focused on solving phylogenetic relationships within orders (Krajewski et al., 1997; Blacket et al., 1999; Jansa et

51 al., 2006; Meredith et al., 2008; Frankham et al., 2012), while the root of the marsupial tree and the 52 relationships among the four Australasian and three South American marsupial orders have not been resolved conclusively with standard sequence data, or morphological evidence (Springer et al., 1998;

54 Horovitz \& Sánchez-Villagra, 2003; Nilsson et al., 2003; Asher et al., 2004; Nilsson et al., 2010).

55 Particularly contentious has been the early branching pattern within Metatheria. For example, it is unclear whether Paucituberculata or Didelphimorphia are the sister group to the remaining marsupials

57 (Meredith et al., 2009). Furthermore, the phylogenetic position of the enigmatic Microbiotheria, represented by only one American species 'monito del monte' (Dromiciops gliroides), differs among studies (Springer et al., 1998; Burk et al., 1999; Amrine-Madsen et al., 2003; Nilsson et al., 2003, 2004), but is usually placed among the Australasian marsupials, implying a biogeographical history

61 that is not straightforward to interpret. However, Nilsson et al., (2010) provided an analysis of

62 retroposon insertions that provide a powerful alternative to sequence data, especially to resolve deeper

63 level relationships. They find support for an intuitively pleasing hypothesis placing all Australasian marsupials in a single clade, as a sister group to Microbiotheria. They also provide strong evidence that Didelphimorphia forms the sister group of the remaining marsupials. A few other studies have studied

66 marsupial species-level relationships mainly within small taxonomic groups (families and subfamilies, genera) or employing relatively sparse taxon sampling (Krajewski et al., 1997, 2012; Blacket et al., 1999; Jansa et al., 2006; Meredith et al., 2008; Malekian et al., 2010; Frankham et al., 2012). Detailed species-level phylogenies underlie modern comparative studies (Harvey \& Pagel, 1991). In general, statistical power of comparative methods increases as taxon sampling and resolution improves. In addition, many methods in the toolkit of comparative biology perform best when branch length estimates are available (Felsenstein, 2004; Bollback, 2006). At present the most detailed 
73 species-level phylogeny of marsupials available is based on a supertree including approximately 260

74 taxa (Cardillo et al., 2004). This phylogeny has already proven to be a high utility tool, underlying

75 various comparative analyses (Weisbecker et al., 2008; Sánchez-Villagra et al., 2008; Flores et al.,

76 2013). Yet, supertrees are essentially summary hypotheses that are stitched together based on smaller

77 phylogenetic studies, and where these are lacking, taxonomy. Thus supertrees are constrained by the

78 available input data, in part summarize opinion rather than primary phylogentic data, often lacking full

79 resolution and typically without accurate estimates of branch lengths. Here we present a species-level

80 phylogeny with branch-length information, including 276 marsupial species, with the primary goal of

81 providing an additional tool for taxonomy, phylogenetic estimation of conservation priorities, and

82 comparative hypothesis testing. We evaluate the 'reliability' of the phylogeny based on the recovery of

83 numerous benchmark clades-previously supported clades and undisputed taxonomic groups

84 (Agnarsson \& May-Collado, 2008).

\section{Material and Methods}

\section{Data and phylogenetic analyses}

88 Sequences for five mitochondrial genes cytochrome b (cytb), ribosomal RNAs 12S and 16S,

89 cytochrome oxidase I (COI), Nicotinamide adenine dinucleotide dehydrogenase subunit 2 (NADH2)

90 and six nuclear genes apolipoprotein B (ApoB), von Willebrand factor (vWF), interphotoreceptor

91 retinoid-binding protein (IRBP), recombination activating gene 1 (Rag1), Breast cancer 1( BRCA1),

92 and Protamine 1 (PRM1) were downloaded these marsupial from GenBank for 271 extant and five

93 extinct species (Table S1). Sequences were downloaded via Mesquite 2.75v (Maddison \& Maddison,

94 2011), aligned in Mafft (Katoh et al. 2002) online (http://www.ebi.ac.uk/) and then reintroduced to

95 Mesquite and manually inspected. When different genes were available for different subspecies we

96 created chimeras to represent the species. We selected 19 outgroups species representing the diversity 
97 of Mammalia, including the orders Monotremata, Pilosa, Pholidota, Chiroptera, Rodentia, Dermoptera,

98 Carnivora, Erinaceomorpha, Soricomorpha, Scandentia, Perissodactyla and the supraorder

99 Cetartiodactyla and the magnaorder Afrotheria. We created several data partitions for sensitivity

100 analyses to explore potential data conflict and source of support, or lack of support for the phylogeny.

101 Conflict and lack of support might be expected because 1) mitochondrial and nuclear genes often differ

102 in estimation of deeper level clades, 2) we identified some alignment issues in the protamine data

103 suggesting potential problems with the source sequences, and 3) the data from GenBank are

104 fragmentary in that most species are missing part of the character data, with some species having less

105 than $10 \%$ data coverage. These partitions consisted of the following matrices: full concatenated matrix

106 (298 taxa, 18,723 bp), full concatenated excluding species with less than 10\% data coverage (251 taxa,

$10718,723 \mathrm{bp}$ ) hereafter referred to as 'focal' analysis, full concatenated minus protamine (296 taxa,

108 17,663bp), concatenated mtDNA (282 taxa, 6,857bp), concatenated nuDNA (242 taxa, 11,866bp),

109 concatenated nuDNA excluding protamine (237 taxa, 10,806bp), and the concatenated the 251 taxa full

110 partitions with a retroposon matrix of Nilsson et al., (2010). Finally, to test if results are sensitive to

111 alignment ambiguities we created a matrix excluding non-protein coding genes (12S and 16S) plus the

112 ambiguously aligned protamine, for a total of eigth partitions.

114 The appropriate models for the Bayesian analysis were selected with jModeltest (Darriba et al., 2012)

115 using the AIC criterion (Posada \& Buckley, 2004) with a UPGMA tree chosen as the basis for

116 Modeltest. The selected models of sequence evolution for Cyt b, 12S, 16S, ApoB, IRBP, RAG 1,

$117 \mathrm{NADH} 2$, and BRCA 1was GTR $+\mathrm{I}+\mathrm{G}$, and for $\mathrm{COI}$ and Protamine 1 the selected models were

$118 \mathrm{HKY}+\mathrm{I}+\mathrm{G}$ and $\mathrm{HKY}+\mathrm{G}$, respectively. The retroposon partition was analyzed under a parsimony

119 model, and alternatively using GTR $+\mathrm{I}+\mathrm{G}$. Bayesian analyses were performed through the CIPRES

120 Science Gateway the maximum time offered by that server (167 hours) using the hybrid version 
121 (CIPRES Science Gateway v3.3) of MrBayes 3.12 (Huelsenbeck \& Ronquist, 2001; Ronquist \&

122 Huelsenbeck, 2003) with settings as in May-Collado \& Agnarsson (2006) and Agnarsson \& May-

123 Collado (2008) with separate model estimation each gene and within protein coding genes for first,

124 second, and third codon positions. The Markov chain Monte Carlo search for each matrix ran with four

125 chains for approximately $18,000,000$ sampling the Markov chain every 1000 generations, and the

126 sample points of the first 5,000,000 generations were discarded as 'burnin', after which the chains had

127 reached approximate stationarity as determined by analysis in Tracer. Maximum likelihood analysess

128 was done in Garli 2.0 (Zwickl, 2006) and MEGA6 on the focal matrix with same partitions as

129 implemented in the Bayesian analysis. Due to computational constraints GARLI was run for 100

130 replicates, and MEGA6 for 100 bootstrap replications. Trees were first manipulated in via Mesquite

$1312.75 \mathrm{v}$ (Maddison \& Maddison, 2011) and then rendered in Adobe Illustrator. Finally, all trees and

132 matrices will be uploaded to Tree Base (submission 16862).

133 As the basal topology of our preferred tree differs from many recent studies, we performed a

134 Shimodaira-Hasawa test (Shimodaira \& Hasawa, 1999) to see if alternative topologies could be

135 rejected. We tested topologies where 1) Didelphimorphia is sister to the remaining Metatheria, 2)

136 where Ameridelphia is monophyletic, and 3) where Australian Australidelphia is monophyletic (that is

137 Microbiotheriidae is sister to other Australidelphia). The test was run in PAUP* (Swofford, 2003)

138 under a GTR $+\mathrm{I}+\mathrm{G}$ model, using one-tailed test (RELL bootstrap) and 1000 bootstrap replicates,

139 starting branch lengths were obtained using the Roger-Swofford approximation method for branch and

140 branch length optimization using one dimensional Newton-Raphson.

\section{Benchmark clades}

143 An intuitive approach of evaluating if the species-level phylogeny will serve, as a reliable comparative 144 tool is the recovery well supported clades from prior studies and undisputed taxonomic groups (May- 
145 Collado \& Agnarsson, 2006; Agnarsson \& May-Collado, 2008). This approach is valuable given the

146 nature of this study. The matrix is based on available data from Genbank rather than markers chosen

147 specifically for the question at hand, some may not be ideal to estimate ancient phylogenetic

148 relationships, and many data are missing in the concatenated matrix. The recovery of benchmark

149 clades is a simple 'reality check', indicating that the analyses are not critically impeded by these

150 shortcomings of the data. A total list of 22 benchmark clades is provided in Table 1.

153 Results

\section{Benchmark clades}

156 With the exception of Phalangeriformes, data partitions in general supported the majority of

157 benchmark clades (Fig. 1). There were notable differences between the mtDNA partition and the 158 remaining partitions. The mtDNA partition data alone resulted in a phylogenetic hypothesis in greater 159 conflict with taxonomy and recent phylogenetic studies than did full concatenated partitions analyses, 160 and the nuDNA partition alone, particularly at lower taxonomic levels (Figs. 1, S1-S5). In the analysis

161 of the full concatenated matrix, many clades have low support and some species appear conspicuously 162 misplaced, such as Marmosa tyleriana (Fig. S1). Excluding protamine from the nuclear partition in 163 general resulted in the same relationships (Fig. S2). Removing from the concatenated analysis taxa

164 with $<10 \%$ character data, our focal analysis, in general recovered the majority of benchmark clades as 165 the full analysis, while support for many clades increased and no species are conspicuously misplaced 166 (Fig. 2-4). The Bayesian analysis with only protein coding genes shows the same relationships as 167 described above. The placement of the Sminthopsis crassicaudata within Diprotodontia seems to be 168 due to an error in classification, the sequence for IRBP was blasted in GenBank and it was $100 \%$ 
169 similar to that of Petrogale xanthopus. However, this error did not impact the results of the overall 170 results presented here. Finally, adding retroposon data to this analysis yielded nearly identical results.

\section{Phylogenetic relationships among orders}

173 The deeper level phylogenetic relationships among orders were consistent between analyses (Fig. 1).

174 These analyses did not support the monophyly of Ameridelphia, but instead placed Paucituberculata as

175 the lineage sister to the remaining marsupials, composed of Didelphimorphia plus Australidelphia. In

176 addition, our results did not support the clade Eometatheria as defined by Kirsch et al., (1997), a clade

177 consisting of Microbiotherida and all autralidelphians excluding peramelians, or as defined by

178 McKenna \& Bell (1997), a clade consisting of the Dasyuromorphia, Notorycterimorphia,

179 Peramelemorphia, Diprotodontia but excluding Microbiotherida. The South American Microbiotheria

180 was the sister lineage of Diprotodontia in all analyses, though this relationship was never strongly

181 supported. The relationship between Dasyuromorphia and Peramelemorphia to the exclusion of

182 Notorycterimorphia was moderately supported by some of the analyses (Fig.1). These results do not

183 support a sister group relationship between the Peramelemorphia and the Diprotodontia expected of the

184 two members of the Grandorder Syndactyli proposed by McKenna \& Bell (1997).

\section{Phylogenetic relationships within orders}

187 Paucituberculata: Within Paucituberculata, the genus Caenolestes was sister to a clade containing

188 Lestoros and Rhyncholestes was strongly supported in the all concatenated and mtDNA analyses (Figs.

189 S1, S4).

191 Didelphimorphia: Within Didelphimorphia, the monophyly of subfamily Caluromyinae as recognized

192 by Voss and Jansa (2009) containing Caluromys and Caluromysiops was supported (Figs. S1-S3). The 
193 only extant species of the subfamily Hyladelphinae (Voss \& Jansa, 2009), the Kalinowski's mouse 194 opossum (Hyladelphys kalinowskii) was sister to Didelphinae and the only member of the subfamily

195 Glironiinae the bushy-tailed opossum, Glironia venusta was placed in most analyses basal to the clade 196 containing the Hyladelphinae and the Didelphinae (Figs. 2, S1-S3). The monophyly of the subfamily

197 Didelphinae (Marmosa, Monodelphis, Tlacuatzin, Metachirus, Chironectes, Didelphis, Lutreolina,

198 Philander and Chacodelphys, Cryptonanus, Gracilinanus, Lestodelphys, Marmosops, and Thylamys)

199 was supported by the all analyses except the mtDNA partition (Fig. S4). The monophyly of the genera

200 Thylamys, Cryptonatus, Marmosops, Monodelphis, Gracilinanus, Philander and Marmosa (plus

201 subgenus Micoureus) were supported by most analyses (Figs. 2, S1-S6). Other interesting relationships

202 include the sister relationship of the genera Cryptonanus and Gracilinanus, the placement of the

203 grayish mouse opossum (Tlacuatzin canescens) sister to Marmosa, and the close relationship of the

204 Patagonian opossum (Lestodelphys halli) with members of the genus Thylamys, and the basal position

205 of the Virginia opossum (Didelphis virginiana) to Philander and the other taxa of Didelphis (Figs. 2,

206 S1-S6).

207

208 Peramelemorphia: Within Peramelemorphia the monophyly of the family Peramelidae was

209 corroborated in three analyses (Fig.1). The extinct member of the family Chaeropodidae the pig-footed

210 bandicoot (Chaeropus ecaudatus) was placed as sister to the remaining peramelemorphians in the full

211 multigene and mtDNA analyses with strong support (Figs. S1, S4). In contrasts, it was placed in the

212 nuDNA partition within the Peramelidae either sister to Echymiperinae (Fig. 3) or within the

213 Microperoryctes (Figs. S2-S3) or within Diprotodontia (Fig. S6) but the support for these placements

214 was low. In six of the analyses the greater bilby, Macrotis lagotis (Thylacomyidae) was placed as sister

215 to the remaining peramelemorphians (Fig. 3, S1, S4, S6). The monophyly of the genera Echymipera,

216 Peroryctes, Isoodon and Perameles was supported by all analyses. The concatenated analyses differed 
217 from the mtDNA partition in the relations among genera. The most supported relationship was

218 ((Echymipera + Microperoryctes) Peroryctes $)+($ Isoodon + Perameles $))($ Figs. 3, S1, S6).

Dasyuromorphia: Within Dasyuromorphia the monophyly of the families Dasyuridae, Myrmecobiidae,

221 and Thylacinidae was supported by most analyses with the interrelationships (Thylacinidae

222 (Myermecobiidae, Dasyuridae)) (Fig1). In two analyses the extinct Tasmanian wolf (Thylacinus

223 cynocephalus) was placed within the subfamily Dasyurinae, but this relationship was poorly supported

224 (Figs. S2, S3). The monophyly of the two Dasyuridae subfamilies Dasyurinae and Sminthopsinae was

225 also supported by most analyses, as well as the two Dasyurinae tribes Dasyurini and Phascogalini and

226 the two Sminthopsinae tribes Planigalini and Sminthopsini (Figs. 3, S1-S4). In most of the analyses the

227 phylogenetic position of Ningaui and the Kultarr (Antechinomys laniger) rendered the genus

228 Sminthopsis paraphyletic (Figs.3, S1-S4). Also highly consistent across analyses is the phylogenetic

229 position of the Mulgara (Dasycercus cristicauda) as sister to the Ningbing fals antechinus,

230 Pseudantechinus ningbing also rendering the later paraphyletic (Figs. 3, S1-S4). The monophyly of the

231 genera Planigale, Murexia, Antechinus, Phascogale, Myoictis, and Dasyurus was supported by most

232 analyses (Figs. 3, S1-S4).

234 Diprotodontia: With the exception of Phalangeriformes the monophyly of other suborders,

235 Vombatiformes (Vombatidae + Phascolarctidae) and Macropodiformes (Hypsiprymnodontidae +

236 Macropodidae + Potoroidea) were supported by all analyses. The monophyly of superfamily

237 Macropodidea was also supported (Fig. 1). The position of Vombatiformes as sister to the remaining

238 Diprododontia was supported by all analyses except the mtDNA partition (Figs. 4, S1-S4). Within the

239 superfamily Petauroidea (Acrobatidae, Tarsipedidae, Pseudocheiriidae, and Petauridae) all partitions

240 except mtDNA supported the position of the family Acrobatidae as the basal petauroids (Figs. 4, S1- 
241 S3). Tarsipedidae was sister to a clade containing Petauridae and Pseudocheiridae. Within Petauridae,

242 the placement of the Gymnobelideus sister to the genus Dactylopsila to the exclusion of Petaurus was

243 strongly supported by both concatenated and the mtDNA partitions (Figs. 4, S1-S4). The monophyly of

244 the Pseudocheiridae was strongly supported as well as that of the subfamilies Pseudocheirinae

245 (Pseudochirulus, Pseudocheirus), Hemibelidinae (Hemibelideus, Petauroides) and Pseudochiropsinae

246 (Petropseudes, Pseudochirops). The monophyly of genus Pseudochirops was not supported is most

247 analyses (Figs. 4, S1-S4). The superfamily Petauroidea is the sister group of Macropodiformes, and

248 Phalangeroidea is the sister group to the clade containing Phalangeridae and Burramyidae (Fig.1).

249 Within the Phalangeridae, the Sulawesi cuscus (Strigocuscus celebensis) was the sister species of the

250 Sulawesi bear (Ailurops ursinus) in all partitions, rendering the genus Strigocuscus paraphyletic and

251 the scaly tailed opossum Wyulda squamicaudata was sister to Trichosurus (Figs. 4, S1-S4). The three

252 kangoroo families Potoroidea, Macropodidae, and Hypsiprymnodontidae were monophyletic and their

253 interrelationships Hypsiprymnodontidae (Potoroidea (Macropodidae) were also supported by all

254 partitions except mtDNA (Figs.1, S1-S4). Within Potoroidea the Rofous bettong, Aepyprymnus

255 rufescens was sister to Bettongia to the exclusion of Potorous (Figs.4, S1-S3). Within Macropodidae,

256 the monophyly of Macropus and Petrogale, was not supported by most analyses (Figs.4, S1-S3). In the

257 full multigene analysis Bennett's tree kangaroo, Dendrolagus bennettianus was the basal species in

258 macropodids (Fig. S1), but for the pruned multigene analysis and nuclear analyses it was instead sister

259 to all Phalanger species (Figs. 4, S2-S3).

\section{Discussion}

262 Our phylogenetic analyses include the largest taxon sampling of extant marsupial species to date,

263 accounting for approximately $80 \%$ of the marsupial diversity currently recognized in Mammal Species

264 of the World (Wilson \& Reeder, 2005) or by the 2012 IUCN Red List of Threatened Species 
265 (http://wwwiucnredlistorg/). Overall, analyses resulted in phylogenetic trees congruent among

266 partitions and in agreement with current phylogenetic knowledge, other than the basal arrangement of

267 the American orders (see below). The mtDNA partitions resulted in deeper level relationships that are

268 inconsistent with existing knowledge, thus the mtDNA data seems to be partially misleading,

269 especially regarding deeper level relationships (Nilsson et al., 2010). However, the mtDNA data

270 corroborates most of the shallower clades, and nuclear data signal appears to trump the mtDNA data in

271 the combined analysis, resulting in hypotheses mostly consistent with taxonomy and current

272 phylogenetic understanding. Missing data, and ambiguity in the protamine data does not seem to have

273 strong impact on the analysis, but these factors in part explain low support for various clades in the full

274 dataset analysis. Support in our focal analysis excluding species with most missing data was higher for

275 many clades (Figs. 2-4). This finding is not surprising, it is well documented that placement of taxa

276 with excessive (>90\%) missing data can be problematic.

278 Root of the Marsupial tree

279 As in most recent phylogenetic analyses, our result fails to support a monophyletic Ameridelphia, a 280 clade only supported by mtDNA in this study and a few other studies (Retief et al., 1995; Springer et 281 al., 1994, 1998). All analyses resulted in the same basal arrangement, (Paucituberculata 282 (Didelphimorphia, Australidelphia)). This conflicts with prior analyses in that the placement of 283 Paucituberculata and Didelphimorphia are switched (Carrillo et al., 2004, Nilsson et al., 2010).

284 However, a likelihood ratio test demonstrated that the alternative topologies consistent with recent 285 studies are not significantly 'worse' explanations of the sequence data. For example, topologies 286 consistent with the retroposon study of Nilsson et al., (2010) and topologies with monophyletic 287 Ameridelphia have only slightly lower likelihoods than the preferred tree (see Table 1). Amrine288 Madsen et al., (2003) also could not discriminate between these hypotheses, but favored rooting at the 
289 base of Didelphimorphia due to the long-branch leading to caenolestids. The sister relationship of

290 Paucituberculata to Australasian marsupials is also supported by morphological characters (Horovitz \&

291 Sánchez-Villagra, 2003) and molecular studies (Baker et al., 2004; Kirsch, 1977; Kirsch et al., 1997).

293 Phylogenetic relationships among orders

294 Our results further place Microbiotheriidae within Australidelphia sister to Diprotodontia, and this 295 relationship is supported independently by the mtDNA and nuDNA. This result is congruent with a 296 previous morphological study that suggested Dromiciops and diprotodontians shared a common 297 ancestor that was hypothesized to have had a prehensile tail and an opposable hallux (Horovitz \& 298 Sánchez-Villagra, 2003). These taxa also share sperm morphology (Gallardo \& Patterson, 1987) and 299 have been supported previously using sequence data (Kirsch et al., 1991), and in a supertrees analysis 300 (Carrillo et al., 2004). However, this arrangement is in conflict with some recent molecular studies 301 (Asher et al., 2004; Beck, 2008; Nilsson et al., 2010). In particular, the recent retroposon analysis of 302 Nilsson et al., (2010) Microbiotheriidae is strongly supported as sister to the Australasian 303 Australidelphia. The latter hypothesis is more congruent with the geographical distribution, placing all 304 Australasian species in a clade and suggesting a single origin of Australasian marsupials. The source of 305 this conflict between sequence and retroposon data is unclear. Future work should profitably focus on 306 adding single-copy nuclear markers, retroposon data for a larger taxon sample, and ultimately 307 employing rich sources of data through next generation sequencing techniques to solidify Marsupialia 308 phylogenetics.

We find a moderately supported relationship between the orders Peramelemorphia and

310 Dasyuromorphia to the exclusion of Notorycterimorphia, similar to previous studies (Baverstock et al.,

311 1990; Kullander et al., 1997; Springer et al., 1997; Beck, 2008; Colgan, 1999; Nilsson et al., 2010).

312 The placement of Notoryctes, has been controversial, with several studies supporting the genus as sister 
313 to Dasyuromorphia (Amrine-Mandsen et al., 2003; Burk et al., 1999; Springer et al., 1998) while others

314 as sister to Peramelemorphia (Baker et al., 2004). Finally, we did not find support for the Eometatheria

315 as contra a prior study combining molecular and morphological data (Asher et al., 2004).

\section{Phylogenetic relationships within orders}

318 Orders Paucituberculata and Didelphimorphia: As found by recent molecular and morphological

319 studies the two Ameridelphian orders Paucituberculata and Didelphimorphia form a grade rather than a 320 clade (Horovitz \& Sánchez-Villagra, 2003; Nilsson et al., 2010). However, we cannot reject the 321 monophyly of Ameridelphia. Our results corroborate Voss and Jansa's (2009) combined morphological 322 and molecular study where Glirona is placed in a monotypic subfamiliy Glironiinae, whereas

323 Caluromys and Caluromysiops remained in the subfamily Caluromyninae. In addition, Hyladelphys

324 was not grouped with other didelphids, thus we support its placement within a subfamily of its own 325 Hyaldephinae (Voss \& Jansa, 2009). However, not all analyses supported Didelphinae tribes

326 (Marmosini, Metachirini, Didelphini, and Thylamyini). The species of the genus Cryptonanus (Voss et 327 al., 2005) were formerly included in the genus Gracilinanus by Gardner \& Creighton (1989). Previous 328 studies have found it difficult to establish the phylogenectic position of Cryptonanus (Jansa et al., 329 2006; Flores, 2009), however, with the exception of the mtDNA analyses we found strong support for a 330 sister relationship between Cryptonanus and Gracilinanus. A close phylogenetic position of the greyish 331 mouse opossum, Tlacuatzin canescens (formely Marmosa canescens) with species of the genus

332 Marmosa (and subgenus Micoureus) is also supported, as has been found in previous studies 333 combining molecules and morphology (Flores, 2009; Voss \& Jansa, 2009). The basal placement of the

334 Peruvian gracile mouse opossum, Hyladelphys kalinowskii in the Didelphinae is also supported by 335 morphological and molecular analyses (Flores, 2009), as well as the close phylogenetic relationship 336 between Patagonian opossum, Lestodelphys halli and the genus Thylamys (Carillo et al., 2004; Jansa et 
al., 2006; Flores, 2009).

Orders Dasyuromorphia: Our results for Dasyuromorphia are largely congruent with previous studies in supporting the monophyly of dasyuromorphian families and subfamilies. The phylogenetic position

341 of the Numbat (Myrmecobius fasciatus) and the Tasmanian wolf (Thylacinus cynocephalus) are

342 traditionally controversial. In this study, most analyses strongly supported the basal placement of the

343 Tasmanian wolf and the Numbat to all dasyuromorphians. This phylogenetic arrangement has been

344 previously supported by morphological (Wroe et al., 2000) and combined analyses (Beck, 2008)

345 including a supertree analysis (Carillo et al., 2004). The position of the Ningaui and the Kultarr

346 (Antechinomys laniger) within Sminthopsis agrees with previous studies (Archer, 1975; Blacket et al.,

347 1999; Carillo et al., 2004) and suggests that taxonomic changes are necessary to accommodate this

348 phylogenetic perspective, In the supertree analysis by Carillo et al., (2004) the Kultarr was referred as

349 Sminthopsis laniger and it was placed as basal to a clade containing Ningaui and Sminthopsis species.

350 Also highly consistent across analyses in this study is the phylogenetic position of the Mulgara,

351 Dasycercus cristicauda as sister to the Ningbing false antechinus, Pseudantechinus ningbing

352 contrasting the results by Carillo et al., (2004).

Order Peramelemorphia: The results from the complete multigene and mtDNA data sets are congruent with recent studies placing the extinct pig-footed bandicoot (Chaeropus ecaudatus) sister to other bandicoots (Carillo et al., 2004; Westerman et al., 2012). Our studies also support a proposed early divergence of the greater bilby, Macrotis lagotis from other bandicoots (Carillo et al., 2004; Meredith et al., 2008; Westerman et al., 2010). The greater bilby is known to be drastically different in their genetic make-up, in that it possesses sixteen autosomes and a multiple sex-chromosome system

360 (Westerman et al., 2010), contrasting with the typical bandicoot chromosome set of $2 \mathrm{n}=14$ (Westerman 
361 et al., 2012). In addition, our results support the close phylogenetic relationships between the two New

362 Guinean subfamilies Echymiperinae and Peroryctinae (Meredith et al., 2008; Westerman et al., 2012).

Order Diprotodontia: Like previous studies our analysis strongly supported the monophyly of

365 Diprotodontia. With the exception of Phalangeriformes the monophyly of the suborders

366 Vombatiformes and Macropodiformes was supported contrasting with one molecular study (Meredith

367 et al., 2009). Amrine-Madsen et al., (2003) found ambivalent support for the monophyly of

368 Phalangeriformes and other studies have been inconclusive (Springer \& Kirsch, 1991; Kirsch et al., 369 1997; Burk et al., 1999). The basal position of Vombatiformes (Vombatidae + Phascolarctidae) is in 370 agreement with previous molecular studies (Meredith et al., 2009; Nilsson et al., 2010).

372 Burramyidae was supported and in accordance with previous studies (Osborne et al., 2002; Beck, 2008;

373 Phillips \& Pratt, 2008; Meredith et al., 2009). Our results are also congruent with previous findings 374 supporting the clade Petauroidea where the families Petauridae and Pseudocheiridae grouped together 375 to the exclusion of Tarsipedidae and Acrobatidae (Osborne et al., 2002; Kavanagh et al., 2004; Phillips 376 \& Pratt, 2008; Meredith et al.,; 2009, 2010). Within the family Petuaridae our results contrast recent 377 molecular studies and previous morphological studies, in that the genus Gymnobelideus grouped with 378 to the genus Dactylopsila to the exclusion of Petaurus (Smith, 1984; Aplin \& Archer, 1987; Springer 379 et al., 1994; Meredith et al., 2010). These results are more in accordance with the molecular analysis of 380 Edwards \& Westerman (1995). Like a previous study (Meredith et al., 2010) we find strong support for 381 the monophyly of the family Pseudocheiridae and three subfamilies. Our results agree with Meredith et 382 al., (2010) in that the genus Pseudochirops is paraphyletic due to the placement of the Australian rockhaunting ringtail possum Petropseudes dahli with New Guinean species of Pseudochirops. Our results 384 are also in agreement with Meredith et al., (2010) in the genera placed in the clades corresponding to 
385 the Pseudocheirinae and Pseudochiropsinae in contrast to the assignments by Groves (2005). Petauroidea grouped with Macropodiformes to the exclusion of Phalangeroidea, contrasting

387 previous studies results (Phillips \& Pratt, 2008; Meredith et al., 2009). As shown by previous studies, 388 the three kangaroo families are monophyletic (Osborne et al., 2002; Meredith et al., 2009; Phillips et

389 al., 2013). One interesting result was the consistent placement of the Sulawesi cuscus, Strigocuscus

390 celebensis sister species to the Sulawesi bear, Ailurops ursinus rendering the genus Strigocuscus

391 paraphyletic. This result agrees with previous molecular studies (Meredith et al., 2009). Within

392 Macropodiformes, the family Hypsiprymnodontidae was sister to a clade consisting of Macropodidae

393 and Potoroidae. This relationship agrees with a previous study (Burk et al., 1998). Within Potoroidae

394 the relationship between Bettongia and Aepyprymnus to the exclusion of Potorous was strongly

395 supported similarly to previous support (Buck et al., 1998). The monophyly of the genus Petrogale was

396 strongly supported by this analysis but phylogenetic relationships among species contrast those

397 proposed by Campeau-Peloquin et al., (2001).

399 Conclusions

400 Here, we offer a summary primary-data phylogeny for marsupials including $80 \%$ of the known

401 marsupial diversity, utilizing a Genbank data-mining approach. Overall results are consistent with

402 previous phylogenetic studies and generally recover undisputed deeper level clades suggesting the

403 present phylogenetic hypotheses should serve as valuable tools for future taxonomic and comparative 404 evolutionary studies.

406 Acknowledgments

407 Support for this work came from the University of Vermont and NSF DEB 1314749 to IA. We thank 408 our Academic Editor for PeerJ Xiaolei Huang, and reviewers Jonathan Fong and Deyan De for their 
comments that greatly improved this manuscript.

\section{References}

413 Abello MA. 2013. Analysis of dental homologies and phylogeny of Paucituberculata (Mammalia:

414 Marsupialia). Biological Journal of the Linnean Society 109:441-465.

416 Agnarsson I, May-Collado LJ. 2008. The phylogeny of Cetartiodactyla: the importance of dense taxon 417 sampling, missing data, and the remarkable promise of Cytochrome $\mathrm{b}$ to provide reliable species-level 418 phylogenies. Molecular Evolution and Phylogenetics 48:964-985. gene sequences provide evidence for the monophyly of australidelphian marsupials Molecular Phylogenetics and Evolution 28:186-196.

424 Aplin KP, Archer M. 1987. Recent advances in marsupial systematics with a new syncretic 425 classification. In: Archer M, ed. Possums and Opossums: Studies in Evolution. Surrey Beatty and the 426 Royal Zoological Society of New South Wales: Sydney, 15-72.

Archer M. 1975. Ningaui, a new genus of tiny dasyurids (Marsupialia) and two new species, from arid Western Australia, N. timealeyi and N. ridei. Memoirs of the Queensland Museum 17: 237-49.

431 Archer MA. 1984. The Australian marsupial radiation. In: Archer M, Clayton G, eds. Vertebrate 432 Zoogeography and Evolution in Australasia. Hesperian Press: Perth, 633-808. 
434 Archer M, Beck R, Gott M, Hand S, Godhelp H, Black K. 2011. Australia's first fossil marsupial mole

435 (Notoryctemorphia) resolves controversies about their evolution and palaenvironemental origins.

436 Proceedings of the Royal Society B-Biological Sciences 278:1498-1506.

438 Asher RJ, Horovitz I, Sánchez-Villagra MR. 2004. First combined cladistics analysis of marsupial 439 mammal interrelationships. Molecular Phylogenetics and Evolution 33:240-250.

441 Asher M, Kirsch J. 2006. The evolution and classification of marsupials. Armati PJ, Dickman CR, 442 Hume ID. Marsupials Cambridge University Press: Cambridge.

444 Baker ML, Wares JP, Harrison GA, Miller RD. 2004. Relationships among the Families and Orders of 445 Marsupials and the major mammalian lineages based on recombination activating Gene-1. Journal of 446 Mammalian Evolution 1:1-16.

448 Baverstock, PR, Kri M, Birrell, J. 1990. Evolutionary relationships of Australian marsupials as 449 assessed by albumin immunology. Australian Journal of Zoology 37:273-287.

451 Baverstock PR, Kri M, Birrell J, Mckay GM.1990. Albumin immunologic relationships of Australian 452 Marsupials II: The Pseudocheiridae. Australian Journal of Zoology 38:519-526.

454 Beck, MDR. 2008. A dated phylogeny of marsupials using a molecular supermatrix and multiple fossil 455 constraints. Journal of Mammalogy 89:175-189. 
457 Blacket MJ, Krajewski C, Labrinidis A, Cambron B, Cooper S, Westerman M. 1999. Systematic 458 relationships within the Dasyurid marsupial tribe Sminthopsini-a multigene approach. Molecular 459 Phylogenetics and Evolution 12:140-155.

460

461 Bollback JP. 2006. SIMMAP: stochastic character mapping of discrete traits on

462 Phylogenies. BMC Bioinformatics 7:88.

463

464 Burk A, Westerman M, Springer M. 1998. The phylogenetic position of the musky rat-kangaroo and 465 the evolution of bipedal hopping in kangaroos (Macropodidae:Diprotodontia). Systematic Biology 47: $466457-474$.

467

468 Burk A, Westerman M, Kao DJ, Kavanagh JR, Springer MS. 1999. An analysis of marsupial 469 interordinal relationships based on 12S rrna, trna valine, 16S rrna, and cytochrome $b$ sequences. 470 Journal of Mammalian Evolution 6, 317-334.

Burk A, Springer MS. 2000. Intergeneric relationships among Macropodoidea (Metatheria:

473 Diprotodontia) and the chronicle of kangaroo evolution. Journal of Mammalian Evolution 7:213-237.

475 Cardillo M, Bininda-Emonds ORP, Boakes E, Purvis A. 2004. A species-level phylogenetic supertree 476 of marsupials. Journal of Zoology (London) 264:11-31.

478 Campeau-Péloquin A, Kirsch JAW, Eldridge MDB, Lapointe FJ. 2001. Phylogeny of the rock479 wallabies, Petrogale (Marsupialia: Macropodidae) based on DNA/DNA hybridization. Australian 480 Journal of Zoology 49:463-486. 
482 Case, JA. 1984. A new genus of Potoroinae (Marsupialia: Macropodidae) from the Miocene

483 Ngapalakdi Local Fauna, South Australia, and a definition of the Potoroinae. Journal of Paleontol $484 \quad 58: 1074-1086$.

485

486 Colgan, DJ. 1999. Phylogenetic studies of marsupials based on phosphoglycerate kinase DNA 487 sequences. Molecular Phylogenetics and Evolution 11:13-26.

488

Darriba D, Taboada GL, Doallo R, Posada D. 2012. Jmodeltest 2: more models, new heuristics and parallel computing. Nature Methods 9: 772.

492 Edwards D, Westerman M. 1995. The molecular relationships of possum and glider families as 493 revealed by DNA-DNA hybridizations. Australian Journal of Zoology 43: 231-240.

495 Felsenstein, J. 2004. Inferring Phylogenies. Sinauer Associates, Sunderland, Massachusetts, pp 531496533.

498 Flannery, T. 1987. A new species of phalanger (Phalangeridae:Marsupialia) from Montane Western 499 Papua New Guinea. Records of the Australian Museum 39: 183-193.

501 Flores, DA. 2009. Phylogenetic analyses of postcranial skeletal morphology in didelphid marsupials.

502 Bulletin of the American Museum of Natural History 320, 81 pp.

504 Flores A, Abdala F, Giannini NP. 2013. Post-weaning cranial ontogeny in two bandicoots (Mammalia, 
505 Perarnelomorphia, Peramelidae) and comparison with carnivorous marsupials. Zoology. 116:372-384.

506

507 Frankham G, Handasyde KA, Eldridge MDB. 2012. Novel insights into the phylogenetic relationships

508 of the endangered marsupial genus Potorus. Molecular Phylogenetics and Evolution 64: 592-602.

509

510 Gallardo MH, Patterson, BD. 1987. An additional 14-chromosome karyotype and sex-chromosome

511 mosaicism in South American marsupials. Fieldiana Zoology 39: 111-116.

512

513 Gardner, AL. 2005a. Order Didelphimorpha. In Wilson DE, Reeder DM, eds. Mammal Species of the

514 World: A Taxonomic and Geographic Reference. $3^{\text {rd }}$ Edition. Baltimore: Johns Hopkins University

515 Press, 3-18.

516

517 Gardner, AL. 2005b. Order Paucituberculata, In Wilson DE, Reeder DM, eds. Mammal Species of the

518 World: A Taxonomic and Geographic Reference. $3^{\text {rd }}$ Edition. Baltimore: Johns Hopkins University

519 Press, 19-20.

520

521 Gardner AL, Creighton GK. 1989. A new generic name for Tate's microtarsus group of South

522 American mouse opossums (Marsupialia: Didelphidae). Proceedings of the Biological Society of

523 Washington 102: 3-7.

524

525 Groves CP. 2005. Order Diprotodontia, In Wilson DE, Reeder DM, eds. Mammal Species of the

526 World: A Taxonomic and Geographic Reference. $3^{\text {rd }}$ Edition. Baltimore: Johns Hopkins University

527 Press, 43-70.

528 
529 Harvey PH, Pagel A. 1991. Comparative methods for explaining adaptations. Nature 351:619-654.

530

531 Hayman DL, Martin PG. 1974. Monetramata and Marsupialia. In: B. John, ed. Animal Cytogenetics.

532 Berlin: Berlin Gebruder Borntraer.

533

534 Horovitz I, Sánchez-Villagra MR. 2003. A morphological analysis of marsupial mammal higher-level 535 phylogenetic relationships. Cladistics 19:181-212.

536

537 Huelsenbeck JP, Ronquist F. 2001. mrbayes: Bayesian inference of phylogenetic trees Bioinformatics. $538 \quad 17: 754-755$.

539

540 Hughes, RL. 1965. Comparative morphology of spermatozoa from five marsupial families. Australian 541 Journal of Zoology. 13:533-543.

542

543 Isaac NJB, Turvey ST, Collen B, Waterman C, Baillie JEM. 2007. Mammals on the EDGE:

544 conservation priorities based on threat and phylogeny. PloS ONE 2(3): e296.

546 Jansa SA, Forsman JF, Voss RS. 2006. Different patterns of selection on the nuclear genes IRBP and

547 DMP-1 affect the efficiency but not the outcome of phylogeny estimation for didelphid marsupials.

548 Molecular Phylogenetics and Evolution 38: 363-380.

550 Katoh K, Misawa K, Kuma K, Miyata T. 2002. MAFFT: a novel method for rapid multiple sequence

551 alignment based on fast Fourier transform. Nucleic Acids Research 30: 3059-3066 
554 Kavanagh JR, Burk-Herrick A, Westerman M, Springer MS. 2004. Relationships among families of

555 Diprotodontia (Marsupialia) and the phylogenetic position of the autapomorphic honey possum

556 (Tarsipes rostratus). Journal of Mammalian Evolution 11:207-222.

558 Kirsch JAW. 1977. The comparative serology of Marsupialia, and a classification of marsupials.

559 Australian Journal of Zoology Supplementary Series No. 52, 152 pp.

561 Kirsch JAW, Calaby JH. 1977. The species of living marsupials: an annotated list. In Stonehouse B,

562 Gilmore DP, eds. The biology of marsupials. London: Macmillian, 9-26.

563

564 Kirsch JAW, Dickerman AW, Reig OA, Springer MS. 1991. DNA hybridization evidence for the 565 Australasian affinity of the American marsupial Dromiciops australis. Proceeding of the National 566 Academy of Sciences of the USA 88: 10465-10469.

568 Kirsch JAW, Lapointe FJ, Springer MS. 1997. DNA hybridization studies of marsupials and their 569 implications for Metatherien classification. Australian Journal of Zoology 45:211-280.

571 Krajewski C, Blacket M, Buckley L, Westerman M. 1997. A multigene assessment of phylogenetic 572 relationships within the Dasyurid marsupial subfamily Sminthopsinae. Molecular Phylogenetics and 573 Evolution 8: 236-248.

575 Krajewski C, Anderson FE, Woolley PA, Westerman M. 2012. Molecular evidence for a deep clade of 576 dunnarts (Marsupialia: Dasyuridae: Sminthopsis). Journal of Mammalian Evolution 19: 265-276. 
578 Kullander K, Carlson B, Hallbook F. 1997. Molecular phylogeny and evolution of the neurotrophins of 579 monotremes and marsupials. Journal of Molecular Evolution 45: 311-321

581 Ladèveze S, de Muizon C. 2010. Evidence of early evolution of Australidephia (Metatheria, 582 Mammalia) in South America : phylogenetic relationships of the metatherians from the Late 583 Palaeocene of Itaborai (Brazil) based on teeth and petrosal bones. Zoological Journal of the Linnean 584 Society 159:746-784

586 Maddison W P, Maddison DR. 2011. Mesquite: a modular system for Evolutionary analysis Version 5872.75 http://mesquiteprojectorg.

589 Malekian M, Cooper SJB, Norman JA, Christidis L, Carthew SM. 2010. Molecular systematics and 590 evolutionary origins of the genus Petaurus (Marsupialia: Petauridae) in Australia and New Guinea. 591 Molecular Phylogenetics and Evolution 54:122-135.

593 Marshall, L G. 1980. Systematics of the South American marsupial family Caenolestidae. Fieldiana 594 Geology 5:1-145.

596 Marshall LG, Case JA, Woodburne MO. 1990. Phylogenetic relationships of the families of 597 marsupials. In HH Genoways, ed. Current Mammalogy. New York: Plenum Press, 433-506.

599 May-Collado LJ, Agnarsson I. 2006. Cytochrome b and Bayesian inference of whale phylogeny. 600 Molecular Phylogenetics and Evolution 38: 344-354. 
601

602 Mckay GM.1984. Cytogenetic relationships of possums and gliders. In AP Smith, ID Hume, eds.

603 Possums and gliders. Sydney, Australia: Beatty and Sons with Australian Mammal Society, 9-16

604

605 Mckenna MC, Bell SK. 1997. Classification of mammals above the species level. Columbia University

606 Press, New York.

607

608 Meredith RW, Westerman M, Springer MS. 2008a. A timescale and phylogeny for "Bandicoots"

609 (Peramelemorphia: Marsupialia) based on sequences for five nuclear genes. Molecular Phylogenetics

610 and Evolution 47:1-20.

611

612 Meredith RW, Westerman M, Springer MS. 2008b. A phylogeny and timescale for the living genera

613 of kangaroos and kin (Macropodiformes: Marsupialia) based on nuclear DNA sequences. Australian

614 Journal of Zoology 56:395-410.

615

616 Meredith RW, Westerman M, Springer MS. 2009. A phylogeny of Diprotodontia (Marsupialia) based

617 on sequences for five nuclear genes. Molecular Phylogenetics and Evolution 51:554-571.

618

619 Meredith RW, Mendoza MA, Roberts KK, Westerman M, Springer MS. 2010. A phylogeny and

620 timescale for the evolution of Pseudocheiridae (Marsupialia: Diprotodontia) in Australia and New

621 Guinea. Journal of Mammalian Evolution 17: 75-99.

622

623 Munemasa M, Nikaido M, Nishihara H, Donnellan S, Austin CC, Okada N. 2008. Newly discovered

624 young CORE-sines in Marsupial genomes. Gene 407: 176-185 
626 Nilsson MA, Gullberg A, Spotorno AE, Arnason U, Janke A. 2003. Radiation of extant marsupials 627 after the K/T boundary: evidence from complete mitochondrial genomes. Journal of Molecular

628 Evolution 57: S3-S12

629

630 Nilsson MA, Arnason U, Spencer PBS, Janke A. 2004. Marsupial relationships and a timeline for 631 marsupial radiation in South Gondwana. Gene 340, 189-196.

632

633 Nilsson MA, Churakov G, Sommer M, Van Tran N, Zemann A, Brosius J, Schmitz J. 2010. Tracking 634 marsupial evolution using archaic genomic retroposon insertions. PloS Biol 8: e1000436.

635

636 Osborne M J, Christidis L, Norman JA. 2002. Molecular phylogenetics of the Diprotodontia 637 (kangaroos, wombats, koala, possums, and allies). Molecular Phylogenetics and Evolution 25: 219638228.

639

640 Palma RE, Spotorno AE. 1999. Molecular systematics of marsupials based on the rrna 12S

641 mitochondrial gene: the phylogeny of Didelphimorphia and of the living fossil Microbiotheriid

642 Dromiciops gliroides Thomas. Molecular Phylogenetics and Evolution 13:525-535

644 Phillips MJ, Mclenachan PA, Down C, Gibb GC, Penny D. 2006. Combined mitochondrial and nuclear 645 DNA sequences resolve the interrelates of the major Australasian Marsupial radiations. Systematic 646 Biology 55:122-137.

647

648 Phillips MJ, Pratt RC. 2008. Family-level relationships among the Australasian marsupial 
649 "herbivores" (Diprotodontia: Koala, wombats, kangaroos and possums). Molecular Phylogenetics and 650 Evolution 46: 594-605.

651

652 Phillips M, Haouchar D, Pratt RC, Gibb GC, Bunce M. 2013. Inferring kangaroo phylogeny from 653 incongruent nuclear and mitochondrial genes. PloS One 8: e57745.

654

655 Posada D, Buckley TR. 2004. Model selection and model averaging in phylogenetics: advantages of 656 akaike information criterion and Bayesian approaches over likelihood ratio tests Systematic Biology $657 \quad 53: 793-808$.

658

659 Prideaux GJ, Warburton N. 2010. An osteology-based appraisal of the phylogeny and evolution of 660 kangaroos and wallabies (Macropodidae: Marsupialia). Zoological Journal of the Linnean Society 159: $661954-987$.

662

663 Raterman D, Meredith RW, Ruedas LA, Springer MS. 2006. Phylogenetic relationships of the cuscuses 664 and brushtail possums (Marsupialia: Phalangeridae) using the nuclear gene BRCA1. Australian 665 Journal of Zoology 54: 353-361.

666

667 Retief JD, Krajewski C, Westerman M, Winkfein RJ, Dixon GH. 1995. Molecular phylogeny and 668 evolution of marsupial Protamine P1 genes. Proceedings of the Royal Society London B 259: 7-14. 669

670 Ride WDL.1961. The cheek-teeth of Hypsiprymnodon moschatus Ramsay 1876 (Macropodidae:

671 Marsupialia). Journal and Proceedings of the Royal Society of Western Australia 44: 53-60. 
673 Ronquist F, Huelsenbeck JP. 2003. Mrbayes 3: Bayesian Phylogenetic Inference under mixed models.

674 Bioinformatics 19, 1572-1574.

675

676 Sánchez-Villagra MR. 2001. The phylogenetic relationships of argyrolagid marsupials. Zoological

677 Journal of the Linnean Society 131:481-496

678

679 Sánchez-Villagra MR, Goswami A, Weisbecker V, Mock O, Kuratani S. 2008.

680 Conserved relative timing of cranial ossification patterns in early mammalian evolution. Evolution and 681 Development 10: 519-530

682

683 Sanclair EA, Westerman M. 1997. Phylogenetic relationships within the genus Potorus (Marsupialia:

684 Potoroidea) based on allozyme electrophoresis and sequence analysis of the cytochrome b gene.

685 Journal of Mammalian Evolution 4:147-161

686

687 Shimodaira H, Hasawa M. 1999. Multiple comparisons of log-likelihoods with applications to 688 phylogenetic inference. Molecular Biology and Evolution 16, 1114-1116

689

690 Smith A. 1984. The species and possums and gliders. In: A Smith, I Hume eds.

691 Possums and Gliders. Sydney, Australia: Beatty and Sons with Australian Mammal Society, 13-15.

692

693 Springer MS. 1993. Phylogeny and rates of character evolution among ringtail possums

694 (Pseudocheridae, Marsupialia). Australia Journal of Zoology 41:273-291.

695

696 Springer MS, Woodburke MO. 1989. The distribution of some basicranial characters within the 
697 Marsupialia and a phylogeny of the Phalangeriformes. Journal of Vertebrate Paleontology 9:210-221.

698

699 Springer MS, Westerman M, Kirsch JAW. 1994. Relationships among orders and

700 Families of marsupials based on 12S ribosomal DNA sequences and the timing of

701 The marsupial radiation. Journal of Mammalian Evolution 2:85-115.

702

703 Springer MS, Kirsch JAW. 1989. Rates of single-copy DNA evolution in phalangeriform marsupials.

704 Molecular Biology and Evolution 6:331-341.

705

706 Springer MS, Kirsch JAW.1991. DNA hybridization, the compression effect, and the radiation of 707 diprotodontian marsupials. Systematic Zoology 40:131-151.

708

709 Springer MS, Kirsch JAW, Case JA. 1997. The chronicle of marsupial evolution In: T Givinish, K

710 Sytsma, eds. Molecular Evolution and Adaptive Radiations. New York: Cambridge University Press, $711 \quad 129-161$.

712

713 Springer MS, Westerman M, Kavanagh JR, Burk A, Woodburne MO, Kao DJ, Krajewski C. 1998.

714 The origin of the Australasian marsupial fauna and the phylogenetic affinities of the enigmatic monitor

715 del monte and marsupial mole. Proceedings of the Royal Society London B 265: 2381-2386

716

717 Swofford, DL. 2003. PAUP* Phylogenetic Analysis Using Parsimony (*and Other Methods) Version

718 4. Sinauer Associates, Sunderland, Massachusetts

719

720 Szalay FS. 1982. Phylogenetic relationships of the marsupials. Geobios Mémoire Spécial 6:177-190. 
722 Voss RS, Jansa SA. 2009. Phylogenetic relationships and classification of didelphid marsupials an

723 extant radiation of the new world metatherian mammals. Bulletin of the American Museum of Natural

724 History 322:1-117.

725

726 Voss RS, Lunde DP, Jansa SA.2005. On the contents of Gracilinanus Gardner and Creighton, 1989,

727 with the description of a previously unrecognized clade of small didelphid marsupials. American

728 Museum Novitates 3482:1-34.

729

730 Weisbecker V, Goswami A, Wroe S, Sánchez-Villagra MR. 2008. Ossification heterochrony in the

731 therian postcranial skeleton and the marsupial-placental dichotomy. Evolution 62: 2027-2041.

732

733 Westerman M, Woolley PA. 1990. Cytogenetics of some New Guinean dasyurids and genemo

734 evolution in the Dasyuridae (Marsupialia). Australian Journal of Zoology 37:521-31.

735

736 Westerman M, Janczewski DN, O’Brien SJ. 1990. DNA-DNA hybridization studies and marsupial

737 phylogeny. Australian Journal of Zoology 37: 315-323.

738

739 Westerman M, Meredith RW, Springer MS. 2010. Cytogenetics meets phylogenetics: a review of

740 karyotype evolution in diprotodontian marsupials. Journal of Heredity 101:690-702.

742 Westerman M, Kear BP, Aplin K, Meredith RW, Emerling C, Springer MS. 2012. Phylogenetic

743 relationships of living and recently extinct bandicoots based on nuclear and mitochondrial DNA

744 sequences. Molecular Phylogenetics and Evolution 62:97-108 
746 Wilson DE, Reeder DM. 2005. Mammal Species of the World: A Taxonomic and Geographic

747 Reference. $3^{\text {rd }}$ edition. Baltimore: Johns Hopkins University Press.

748

749 Wroe S, Ebatch M, Ahyong S, de Muizon C, Muirhead J. 2000. Cladistic analysis of dasyuromorphian

750 (Marsupialia): Phylogeny using cranial and dental characters. Journal of Mammalogy 81:1008-1024.

751

752 Zwickl, D. J., 2006. Genetic algorithm approaches for the phylogenetic analysis of large

753 biological sequence datasets under the maximum likelihood criterion. Ph.D. dissertation,

754 The University of Texas at Austin.

755

756

757

758 Table 1. Summary of benchmark clades supported by multiple studies. The list of references

759 accompanying each clade is meant to be representative, not an exhaustive review of supporting studies.

760

761 Table 2. Results from the Shimodaira-Hasagawa evaluating alternative topologies compared to the

762 focal analysis (concatenated analysis removing taxa with $<10 \%$ character data cover).

763

764 Figure Legends

765 Figure 1. Summary cladogram of all the analyses showing support for relationships among major 766 clades within Metatheria. 
768 Figure 2. Majority rule consensus of the Bayesian analyses using the focal concatenated character 769 matrix (excluding species with less than 10\% data coverage) for Ameridelphia. Note that Micoureus

770 was recently recognized as a subgenus of Marmosa (IUCN Red List of Threatened Spcies 2013.2).

771 Node numbers are posterior probabilities, omitted when less than $50 \%$. Extinct species are indicated 772 with a cross. Photos obtained from Wikimedia Commons.

773

774 Figure 3. Majority rule consensus of the Bayesian analyses using the focal concatenated character 775

776

777

778

779

780

781 Figure 4. Majority rule consensus of the Bayesian analyses using the focal concatenated character 782 783 784 785 786

\section{Supplementary Material} melanurus, and Paramurexia rothschildi are now recognized as members of the genus Murexia (IUCN

791 Red List of Threatened Spcies 2013.2). 
793 Table S2. Detailed results from the Shimodaira-Hasagawa test evaluating alternative topologies 794 compared to the focal analysis (tree $1=$ focal analysis, tree $2=$ Ameridelphia monophyletic, tree $3=$ 795 Didelphimorphia basal, tree4= Retroposon tree by Nilsson et al., 2010).

796

797 Figure S1. Metatheria majority rule consensus of the Bayesian analyses using the full concatenated

798 character matrix. Note that Micoureus was recently recognized as a subgenus of Marmosa, and

799 Antechinus naso, Antechinus melanurus, and Paramurexia rothschildi are now recognized as members

800 of the genus Murexia (IUCN Red List of Threatened Spcies 2013.2).

803 Figure S2. Metatheria majority rule consensus of the Bayesian analyses using the full concatenated 804 character matrix excluding protamine. Note that Micoureus was recently recognized as a subgenus of 805 Marmosa, and Antechinus naso, Antechinus melanurus, and Paramurexia rothschildi are now 806 recognized as members of the genus Murexia (IUCN Red List of Threatened Spcies 2013.2) 807

808 Figure S3. Metatheria majority rule consensus of the Bayesian analyses using the nuDNA concatenated 809 character matrix excluding protamine. Note that Micoureus was recently recognized as a subgenus of 810 Marmosa, and Antechinus naso, Antechinus melanurus, and Paramurexia rothschildi are now 811 recognized as members of the genus Murexia (IUCN Red List of Threatened Spcies 2013.2) 812

813 Figure S4. Metatheria majority rule consensus of the Bayesian analyses using the mtDNA concatenated 814 character matrix. Note that Micoureus was recently recognized as a subgenus of Marmosa, and 
815 Antechinus naso, Antechinus melanurus, and Paramurexia rothschildi are now recognized as members

816 of the genus Murexia (IUCN Red List of Threatened Spcies 2013.2).

817

818 Figure S5. Metatheria majority rule consensus of the Bayesian analyses using a matrix excluding non-

819 protein coding genes (12S and $16 \mathrm{~S}$ ) plus the ambiguously aligned protamine. Note that Micoureus was

820 recently recognized as a subgenus of Marmosa, and Antechinus naso, Antechinus melanurus, and

821 Paramurexia rothschildi are now recognized as members of the genus Murexia (IUCN Red List of

822 Threatened Spcies 2013.2).

823

824 Figure S6. Maximum likelihood tree using excluding species with less than $10 \%$ data coverage. Note 825 that Micoureus was recently recognized as a subgenus of Marmosa, and Antechinus naso, Antechinus 826 melanurus, and Paramurexia rothschildi are now recognized as members of the genus Murexia (IUCN 827 Red List of Threatened Spcies 2013.2).

828 


\section{Table $\mathbf{1}$ (on next page)}

Summary of benchmark clades supported by multiple studies.

The list of references accompanying each clade is meant to be representative, not an exhaustive review of supporting studies. 
2 Table 1. Summary of benchmark clades supported by multiple studies. The list of references accompanying each clade is meant to be 3 representative, not an exhaustive review of supporting studies.

\begin{tabular}{|c|c|c|c|}
\hline Benchmark clade & Description & Morphology & Molecular \\
\hline Australidephia & $\begin{array}{l}\text { This superorder contains all Australian } \\
\text { marsupials and a single species from } \\
\text { South America (monito del monte, } \\
\text { Dromiciops gliroides) }\end{array}$ & $\begin{array}{l}\text { Horovitz \& Sánchez- } \\
\text { Villagra (2003), Asher et } \\
\text { al., 2004, Ladèveze \& de } \\
\text { Muizon (2010) }\end{array}$ & $\begin{array}{l}\text { Kirsch et al., (1991), Colgan (1999), } \\
\text { Palma \& Spotorno (1999), Amrine- } \\
\text { Madsen et al., (2003), Baker et al., (2004), } \\
\text { Nilsson et al., (2004), Phillips et al., } \\
\text { (2006), Beck (2008), Meredith et al., } \\
\text { (2008, 2009), Nilsson et al., (2010), } \\
\text { Westerman et al., (2010) }\end{array}$ \\
\hline Diprotodontia & $\begin{array}{l}\text { This is the largest order of marsupials } \\
\text { and is distinguished from other } \\
\text { marsupials by having syndactylous } \\
\text { digits and two procumbent lower } \\
\text { incisors (diprotodont) }\end{array}$ & $\begin{array}{l}\text { Horovitz \& Sánchez- } \\
\text { Villagra (2003), Asher et } \\
\text { al., } 2004\end{array}$ & $\begin{array}{l}\text { Baverstock et al., (1990), Burk et al., } \\
\text { (1999), Colgan (1999), Osborne et al., } \\
\text { (2002), Amrine-Madsen et al., (2003), } \\
\text { Phillips et al., (2006), Meredith et al., } \\
\text { (2008, 2009), Munemasa et al., (2008), } \\
\text { Phillips \& Pratt (2008), Nilsson et al., } \\
\text { (2010), Westerman et al., (2010) }\end{array}$ \\
\hline Phalangeriformes & $\begin{array}{l}\text { This suborder of Diprotodontia contains } \\
\text { medium sized arboreal marsupials from } \\
\text { Australia, New Guinea and Sulawesi }\end{array}$ & $\begin{array}{l}\text { Flannery (1987), Springer } \\
\text { \& Woodburke (1989) }\end{array}$ & $\begin{array}{l}\text { Springer \& Kirsch (1989, 1991), Amrine- } \\
\text { Madsen et al., (2003), Phillips \& Pratt } \\
\text { (2008), Meredith et al., (2009) }\end{array}$ \\
\hline Phalangeroidea & $\begin{array}{l}\text { This superfamily of Phalangeriformes } \\
\text { contains two families Phalangeridae and } \\
\text { Burramyidae }\end{array}$ & & $\begin{array}{l}\text { Colgan (1999), Meredith et al., (2008), } \\
\text { Westerman et al., (2010) }\end{array}$ \\
\hline Phalangeridae & $\begin{array}{l}\text { This family of Phalangeroidea contains } \\
\text { brushtail possums and cuscuses }\end{array}$ & Hughes (1965) & $\begin{array}{l}\text { Osborne et al., (2002), Baker et al., } \\
\text { (2004), Kavanagh et al., (2004) Raterman } \\
\text { et al., (2006), Beck (2008), Meredith et } \\
\text { al., (2009). }\end{array}$ \\
\hline Burramyidae & $\begin{array}{l}\text { This family of Phalangeroidea contains } \\
\text { pygmy possums }\end{array}$ & Archer (1984) & $\begin{array}{l}\text { Barverstock et al., (1990), Edwards \& } \\
\text { Westerman (1995), Osborne \& Christidis } \\
\text { (2002), Beck (2008) }\end{array}$ \\
\hline Petauroidea & This superfamily of Phalangeriformes & & Osborne et al., (2002), Amrine-Madsen et \\
\hline
\end{tabular}




\begin{tabular}{|c|c|c|c|}
\hline & $\begin{array}{l}\text { contains four families, Pseudocheiridae, } \\
\text { Petauridae, Tarsipedidae, and } \\
\text { Acrobatidae }\end{array}$ & & $\begin{array}{l}\text { al., (2003), Kavanagh et al., 2004, } \\
\text { Meredith et al., (2008), Phillips \& Pratt } \\
\text { (2008), Meredith et al., (2010), } \\
\text { Westerman et al., (2010). }\end{array}$ \\
\hline Pseudocheiridae & $\begin{array}{l}\text { This family of the superfamily } \\
\text { Petauroidea contains ringtail possums }\end{array}$ & $\begin{array}{l}\text { Archer (1984), Springer } \\
\text { (1993) }\end{array}$ & $\begin{array}{l}\text { Hayman \& Martin (1974), Barverstock et } \\
\text { al., (1990), Westerman et al., (1990), } \\
\text { Baverstock et al., (1999), Osborne \& } \\
\text { Christidis (2001), Meredith et al., (2010) }\end{array}$ \\
\hline Petauridae & $\begin{array}{l}\text { This family of the superfamily } \\
\text { Petauroidea contains gliders, } \\
\text { Leadbeater's possum, and the striped } \\
\text { possum and trioks }\end{array}$ & $\begin{array}{l}\text { Aplin \& Archer (1987), } \\
\text { Smith (1984) }\end{array}$ & $\begin{array}{l}\text { Kirsch \& Calaby (1977), McKay (1984), } \\
\text { Barverstock et al., (1990), Osborne \& } \\
\text { Christidis (2001), Meredith et al., (2010). }\end{array}$ \\
\hline Acrobatidae & $\begin{array}{l}\text { This family of the superfamily } \\
\text { Petauroidea contains feather-tailed } \\
\text { gliders and feather-tailed possum }\end{array}$ & & $\begin{array}{l}\text { Barverstock et al., (1990), Baker et al., } \\
\text { (2004). }\end{array}$ \\
\hline Macropodiformes & $\begin{array}{l}\text { This suborder of Diprotodontia contains } \\
\text { kangaroos, wallabies, and allies } \\
\text { (bettongs, potaroos, and rat kangaroos) }\end{array}$ & $\begin{array}{l}\text { Ride (1961), Case (1984), } \\
\text { Flannery (1987) }\end{array}$ & $\begin{array}{l}\text { Kirsch (1977), Burk \& Springer (2000), } \\
\text { Kavanagh et al., (2004), Meredith et al., } \\
(2008,2009) \text {, Westerman et al., (2010) }\end{array}$ \\
\hline Macropodoidea & $\begin{array}{l}\text { This superfamily of Macropodiformes } \\
\text { consists of two families the } \\
\text { Macropodidae and Potoroidae that form } \\
\text { a clade distinct from the rat kangaroo, } \\
\text { family Hypsiprymnodontidae }\end{array}$ & & $\begin{array}{l}\text { Barverstock et al., (1990), Burk et al., } \\
\text { (1998), Colgan (1999), Osborne et al., } \\
\text { (2002), Meredith et al., (2008b), Phillips } \\
\text { \& Pratt (2008). }\end{array}$ \\
\hline Macropodidae & $\begin{array}{l}\text { This family of Macropodoidea contains } \\
\text { the major diversity of marsupial } \\
\text { hervibores, including kangaroos, } \\
\text { wallabies, tree-kangaroos and several } \\
\text { others }\end{array}$ & $\begin{array}{l}\text { Horovitz \& Sánchez- } \\
\text { Villagra (2003), Prideaux } \\
\text { \& Warburton (2010) }\end{array}$ & $\begin{array}{l}\text { Barverstock et al., (1990), Burk et al., } \\
\text { (1998), Baker et al., (2004), Kavanagh et } \\
\text { al., 2004, Meredith et al., (2008b), } \\
\text { Meredith et al., (2009). }\end{array}$ \\
\hline Potoridae & $\begin{array}{l}\text { This family of Macropodoidea contains } \\
\text { bettongs }\end{array}$ & $\begin{array}{l}\text { Archer (1984), Flannery } \\
\text { et al., (1984), Flannery } \\
1989\end{array}$ & $\begin{array}{l}\text { Barverstock et al., (1990), Sanclair \& } \\
\text { Westerman (1997), Burk et al., (1998), } \\
\text { Meredith et al., (2008b). }\end{array}$ \\
\hline
\end{tabular}




\begin{tabular}{|c|c|c|c|}
\hline Vombatiformes & $\begin{array}{l}\text { This suborder of Diprotodontia consists } \\
\text { of two families Phascolarctidae and } \\
\text { Vombatidae }\end{array}$ & Hughes (1965) & $\begin{array}{l}\text { Barverstock et al., (1990), Burk et al., } \\
\text { (1999) (mtDNA), Osborne et al., (2002), } \\
\text { Amrine-Madsen et al., (2003), Baker et } \\
\text { al., (2004) (RAG1), Kavanagh et al., } \\
\text { 2004, Meredith et al., (2008, 2009), } \\
\text { Phillips \& Pratt (2008), Westerman et al., } \\
\text { (2010). }\end{array}$ \\
\hline Dasyuromorphia & $\begin{array}{l}\text { This order of marsupials contains most } \\
\text { of Australian carnivorous marsupials } \\
\text { consisting of three families Dasyuridae, } \\
\text { Myrmecobiidae, and Thylacinidae }\end{array}$ & $\begin{array}{l}\text { Wroe et al., (2000), } \\
\text { Horovitz \& Sánchez- } \\
\text { Villagra (2003), } \\
\text { Ladèveze \& de Muizon } \\
(2010)\end{array}$ & $\begin{array}{l}\text { Burk et al., (1999), Amrine-Madsen et al., } \\
\text { (2003), Kavanagh et al., 2004, Beck } \\
(2008) \text {, Meredith et al., (2009), Nilsson et } \\
\text { al., (2010), Westerman et al., (2010). }\end{array}$ \\
\hline Dasyuridae & $\begin{array}{l}\text { This family of Dasyuromorphia consists } \\
\text { of terrestrial and arboreal species, many } \\
\text { of which lack a pouch }\end{array}$ & $\begin{array}{l}\text { Wroe et al., (2000), Asher } \\
\text { \& Kirsch (2006) }\end{array}$ & $\begin{array}{l}\text { Westerman \& Woolley (1990), Colgan } \\
\text { (1999), Baker et al., (2004), Meredith et } \\
\text { al., (2008). }\end{array}$ \\
\hline Notoryctemorphia & $\begin{array}{l}\text { This order of marsupials contains two } \\
\text { species of marsupial moles, Notoryctes } \\
\text { caurinus and } N \text { typhlops }\end{array}$ & $\begin{array}{l}\text { Aplin \& Archer (1987), } \\
\text { Archer et al., (2011) }\end{array}$ & $\begin{array}{l}\text { Barverstock et al., (1990), Springer et al., } \\
\text { (1998), Nilsson et al., (2010) }\end{array}$ \\
\hline Peramelemorphia & $\begin{array}{l}\text { This order of marsupials consists of } \\
\text { three families Peramelidae, } \\
\text { Chaeropodidae and Thylacomidae }\end{array}$ & $\begin{array}{l}\text { Wroe et al., (2000), } \\
\text { Horovitz \& Sánchez- } \\
\text { Villagra (2003), Asher et } \\
\text { al., 2004, Ladèveze \& de } \\
\text { Muizon (2010) }\end{array}$ & $\begin{array}{l}\text { Burk et al., (1999), Amrine-Madsen et al., } \\
\text { (2003), Asher et al., 2004, Baker et al., } \\
\text { (2004), Kavanagh et al., 2004, Beck } \\
\text { (2008), Meredith et al., (2008, 2009), } \\
\text { Nilsson et al., (2010), Westerman et al., } \\
\text { (2010, 2012). }\end{array}$ \\
\hline Peramelidae & $\begin{array}{l}\text { This family of the Peramelemorphia } \\
\text { contains bandicoots and echymiperas }\end{array}$ & & $\begin{array}{l}\text { Phillips et al., (2006), Meredith et al., } \\
\text { (2008), Westerman et al., (2012). }\end{array}$ \\
\hline Paucituberculata & $\begin{array}{l}\text { This order of shrew opossums is } \\
\text { represented by a single family } \\
\text { Caenolestidae }\end{array}$ & $\begin{array}{l}\text { Marshall (1980), } \\
\text { Sánchez-Villagra (2001), } \\
\text { Asher \& Kirsch (2006), }\end{array}$ & $\begin{array}{l}\text { Amrine-Madsen et al., (2003), Nilsson et } \\
\text { al., (2004), Phillips et al., (2006), } \\
\text { Meredith et al., (2008), Nilsson et al., }\end{array}$ \\
\hline
\end{tabular}




\begin{tabular}{|l|l|l|l|}
\hline & & $\begin{array}{l}\text { Ladèveze \& de Muizon } \\
\text { (2010),(Abello (2013) }\end{array}$ & $($ 2010) \\
\hline Didelphimorphia & $\begin{array}{l}\text { This order of new world marsupials } \\
\text { diversified mainly in South America and } \\
\text { consists of a single family Didelphidae }\end{array}$ & $\begin{array}{l}\text { Horovitz \& Sánchez- } \\
\text { Villagra (2003), Asher \& } \\
\text { Kirsch (2006), Ladèveze } \\
\text { \& de Muizon (2010) }\end{array}$ & $\begin{array}{l}\text { Burk et al., (1999), Amrine-Madsen et al., } \\
\text { (2003), Baker et al., (2004), Kavanagh et } \\
\text { al., 2004, Nilsson et al., (2004), Phillips et } \\
\text { al., (2006), Meredith et al., (2008), } \\
\text { Nilsson et al., (2010). }\end{array}$ \\
\hline
\end{tabular}


Table 2 (on next page)

Results from the Shimodaira-Hasagawa evaluating alternative topologies compared to the focal analysis (concatenated analysis removing taxa with $<10 \%$ character data cover). 
3 Table 2. Results from the Shimodaira-Hasagawa evaluating alternative topologies compared to the 4 focal analysis (concatenated analysis removing taxa with $<10 \%$ character data cover).

5

6

\begin{tabular}{lccc}
\hline \multicolumn{1}{c}{ Tree Constraint } & -InL & Diff -InL & P \\
\hline $\begin{array}{l}\text { Ameridelphia } \\
\text { monophyletic }\end{array}$ & 435351.2 & 5.84062 & 0.463 \\
$\begin{array}{l}\text { Didelphimorphia is sister } \\
\text { to the remaining }\end{array}$ & 435353.4 & 2.22915 & 0.725 \\
$\begin{array}{l}\text { Marsupialia } \\
\begin{array}{l}\text { Australian Australidelphia } \\
\text { monophyletic (that is }\end{array}\end{array}$ & 435361.1 & 9.91611 & \\
$\begin{array}{l}\text { Microbiotheriidae is sister } \\
\text { to other Australidelphia) } \\
\text { (Nilsson et al., 2010) }\end{array}$ & & & \\
\hline
\end{tabular}


1

Summary cladogram of all the analyses showing support for relationships among major clades within Metatheria 


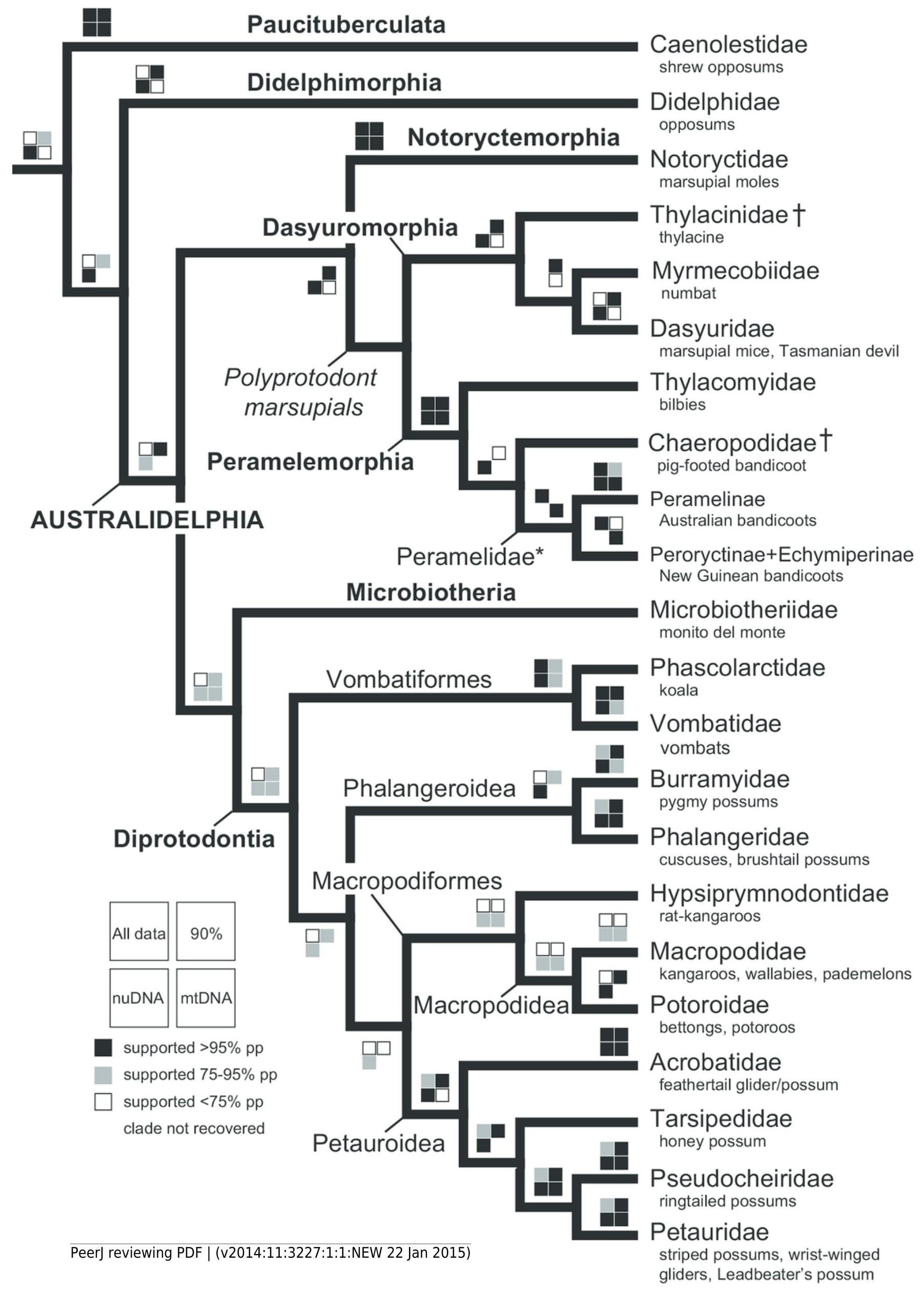


2

Majority rule consensus of the Bayesian analyses using the focal concatenated character matrix (excluding species with less than $10 \%$ data coverage) for Ameridelphia.

Note that Micoureus was recently recognized as a subgenus of Marmosa (IUCN Red List of Threatened Spcies 2013.2). Node numbers are posterior probabilities, omitted when less than $50 \%$. Extinct species are indicated with a cross. Photos obtained from Wikimedia Commons. 


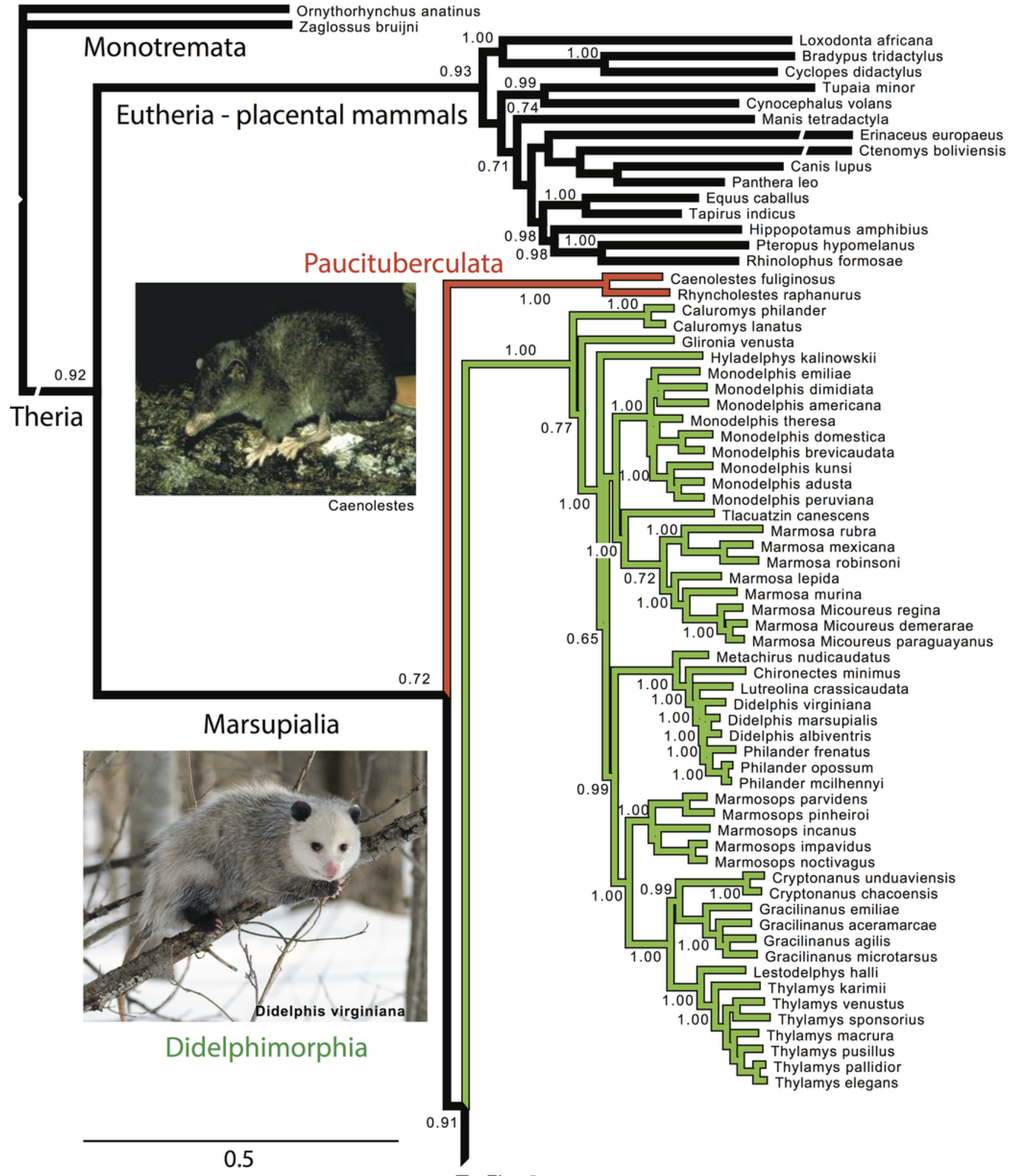

To Fig. 3 
3

Majority rule consensus of the Bayesian analyses using the focal concatenated character matrix for Australasian marsupials: Notoryctemorphia, Peramelemorphia, and Dasyuromorphia.

Note that the species Antechinus naso, Antechinus melanurus, and Paramurexia rothschildi are now recognized as members of the genus Murexia (IUCN Red List of Threatened Spcies 2013.2). Node numbers are posterior probabilities, omitted when less than $50 \%$. Photos obtained from Wikimedia Commons. 


\section{Notoryctemorphia}
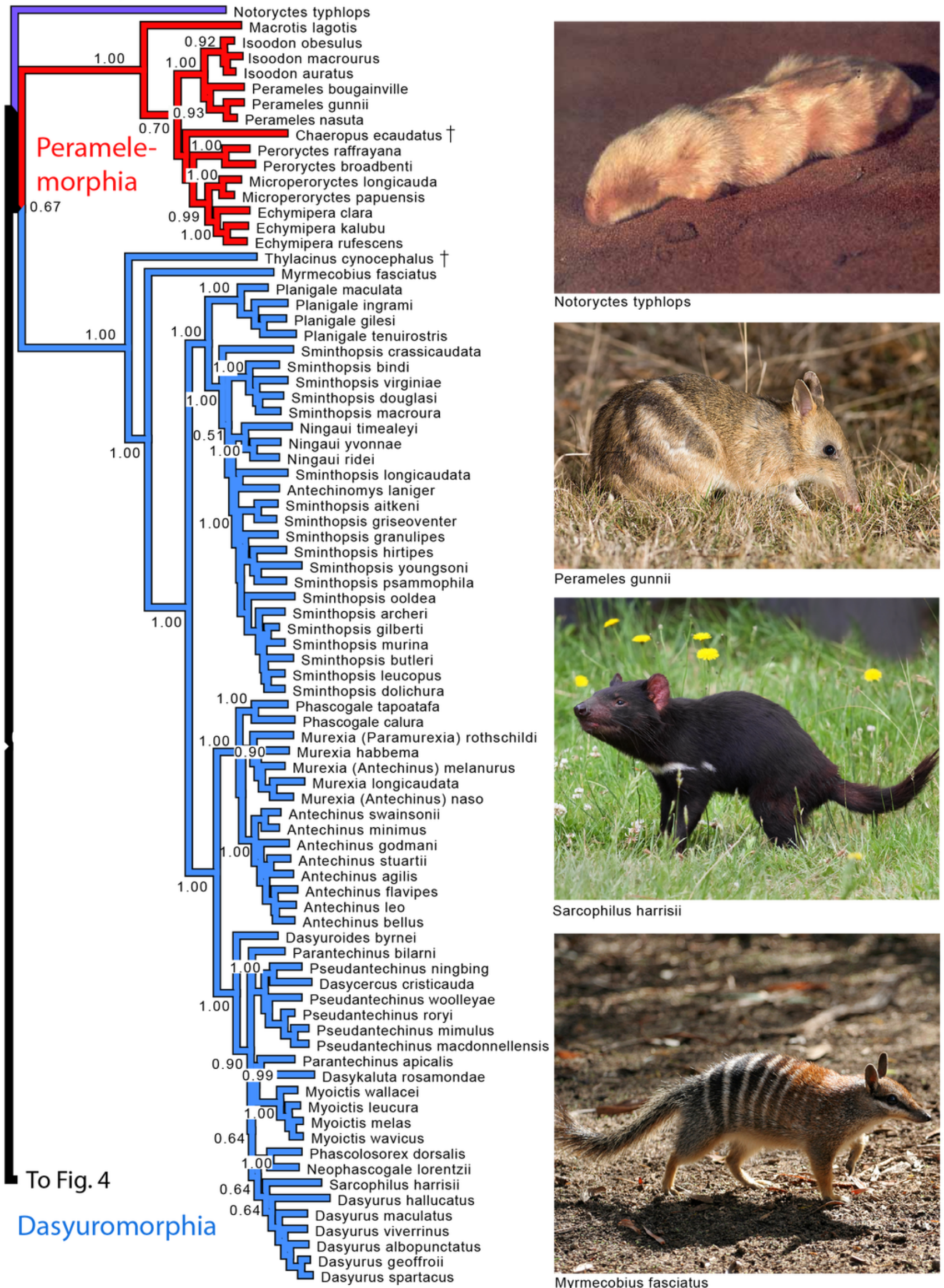

Notoryctes typhlops

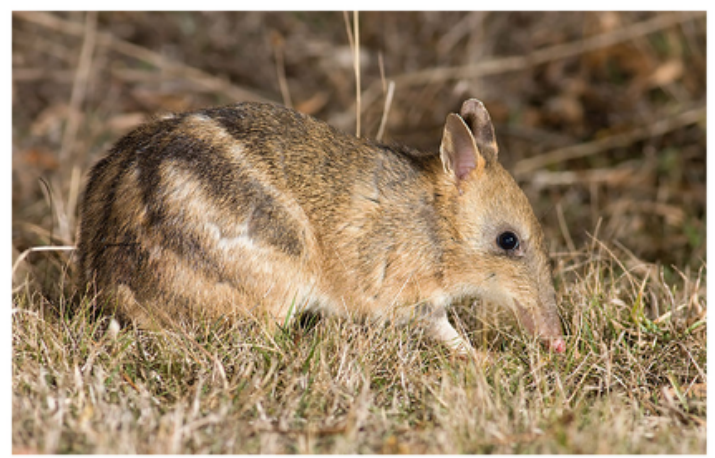

Perameles gunnii

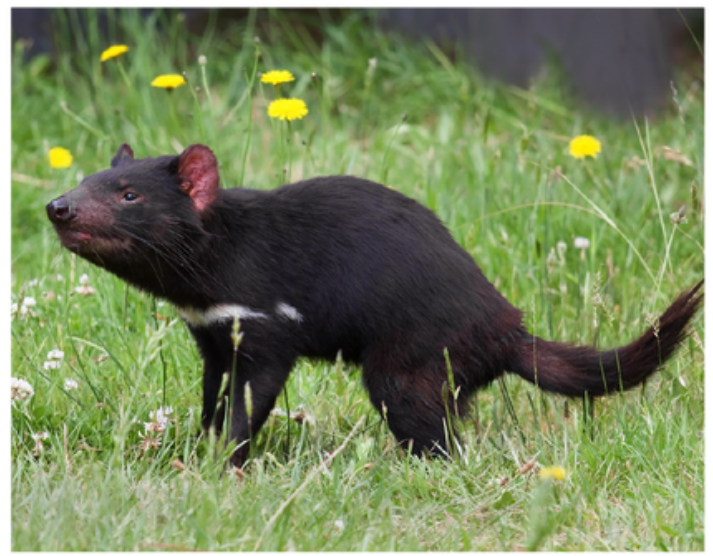

Sarcophilus harrisii

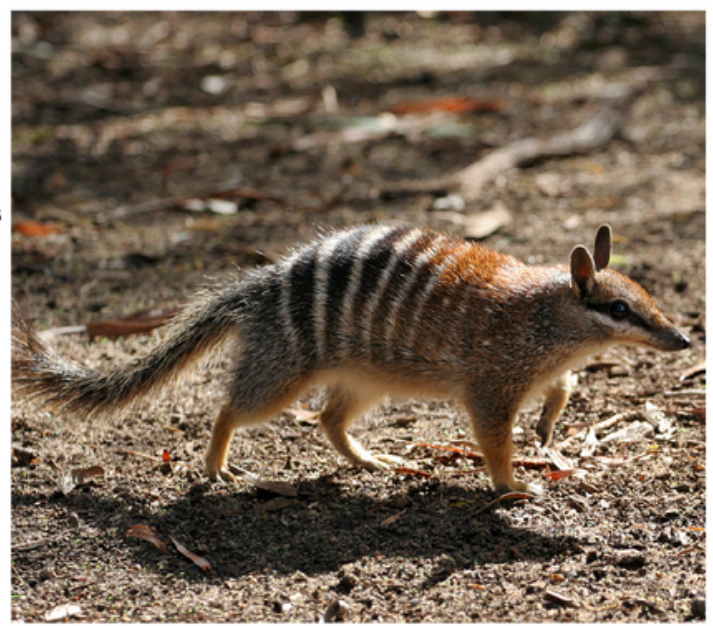

Myrmecobius fasciatus 
4

Majority rule consensus of the Bayesian analyses using the focal concatenated character matrix for Australasian marsupials: Diprotodontia.

Node numbers are posterior probabilities, omitted when less than $50 \%$. Photos obtained from Wikimedia Commons. 


\section{Microbiotheriidae}

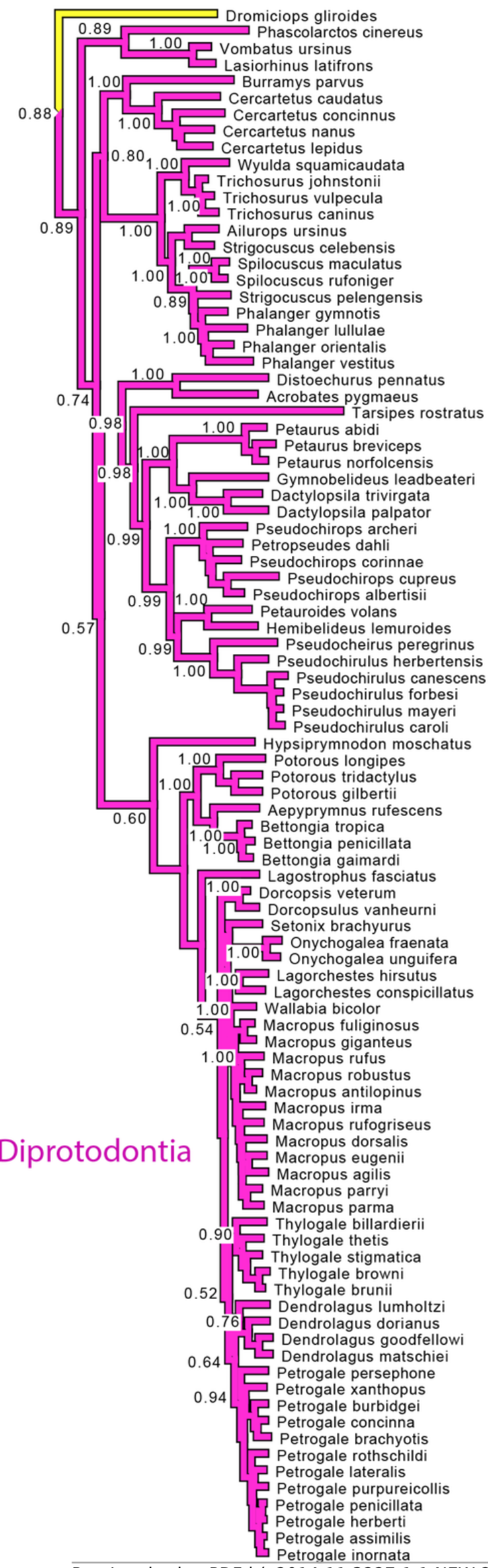

Peer) reviewing PDF $\mid(v 2014 \cdot 11 \cdot 3227 \cdot 1 \cdot 1 \cdot$ NEW 22 Jan 2015

0.5
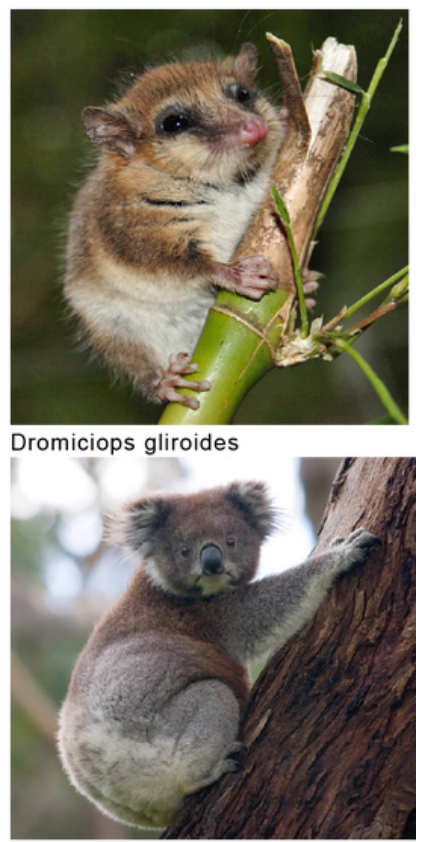

Phascolarctos cinereus

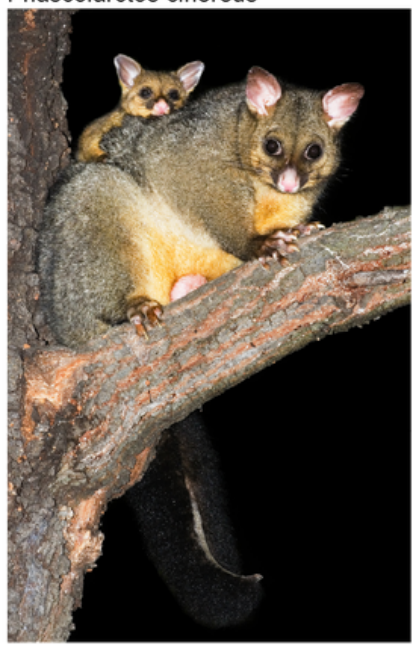

Trichosurus vulpecula



Macropus giganteus

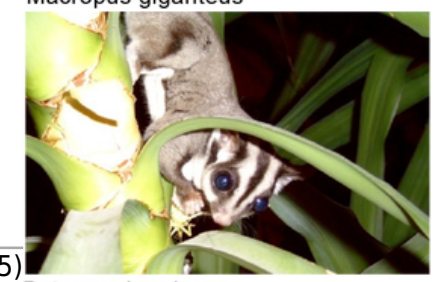

